\title{
Biostimulants Based on Humic Acids, Amino Acids and Vitamins Increase Growth and Quality of Lettuce Seedlings
}

\author{
Rubens Ribeiro da Silva ${ }^{1}$, Antonio Carlos Martins dos Santos ${ }^{1}$, Jefferson Santana da Silva Carneiro ${ }^{2}$, \\ Lara Couto Marques ${ }^{1}$, Larissa Urzêdo Rodrigues ${ }^{1}$, Alvaro José Gomes de Faria ${ }^{1}$, Gilson Araújo de Freitas ${ }^{1}$ \\ \& Vitor L. Nascimento ${ }^{1}$ \\ ${ }^{1}$ Plant Production Graduate Program, Universidade Federal do Tocantins, Gurupi, Tocantins, Brazil \\ ${ }^{2}$ Department of Soil Science, Universidade Federal de Lavras, Lavras, Minas Gerais, Brazil \\ Correspondence: Vitor L. Nascimento, Plant Production Graduate Program, Universidade Federal do Tocantins, \\ Gurupi, TO 77402-970, Brazil. Tel: 55-633-311-1646. E-mail: vitorlnasc@gmail.com \\ Rubens Ribeiro da Silva, Plant Production Graduate Program, Universidade Federal do Tocantins, Gurupi, TO \\ 77402-970, Brazil. Tel: 55-633-311-3562. E-mail: rrs2002@uft.edu.br
}

$\begin{array}{ll}\text { Received: January 27, } 2019 & \text { Accepted: March 10, } 2019 \quad \text { Online Published: May 15, } 2019 \\ \text { doi:10.5539/jas.v11n6p235 } & \text { URL: https://doi.org/10.5539/jas.v11n6p235 }\end{array}$

This study was financed in part by the Coordenação de Aperfeiçoamento de Pessoal de Nivel Superior-Brasil (CAPES)-Finance Code 001.

\begin{abstract}
Humic acids (HA), amino acids (AA) and vitamins can increase plant growth; however, there are still few studies that determine the ideal concentration for use in lettuce (Lactuca sativa L.) production. Research was conducted to evaluate the effects of HA enriched with sources and levels of AA and vitamins on lettuce seedlings morphology and quality. Two experiments were conducted in a completely randomized design with four replicates. The first experiment had 16 treatments, $3 \times 5+1$ factorial design, the first factor was betaine, glycine and proline used in the HA enrichment, and second factor five concentrations of AA $(0,0.5,1.0,1.5$, and $2.0 \mathrm{~g}$ $\mathrm{L}^{-1}$ ), plus the control, without HA and AA. The second experiment had 21 treatments, $4 \times 5+1$ factorial design, the first factor was the use of four vitamins (A, E, B1 and B2) in the enrichment of HA, while the second factor was composed of five concentrations of each vitamin $\left(0,0.5 ; 1.0,1.5\right.$, and $\left.2.0 \mathrm{~g} \mathrm{~L}^{-1}\right)$ plus the control, without HA and vitamins. The application of HA and HA+AA promote the improvement in the seedling's morphology and quality, while the application of the HA+vitamins negatively affected the morphology, reducing seedling quality.
\end{abstract}

Keywords: growth regulator, humic substances, Lactuca sativa L., plant nutrition

\section{Introduction}

Biostumulants are substances and/or microorganisms that promote plant growth and development. The global market of these products is projected to reach $\$ 2.24$ billion by 2018 with an annual growth rate of $12.5 \%$ between 2013 and 2018 (Calvo et al., 2014). These products are considered low-cost and high value-added, as well as a promising technology for plant cultivation, since they increase productivity with low investment and in a sustainable manner (Meirelles et al., 2017).

The beneficial effects of the biostimulants use have been reported in several crops including asparagus, Asparagus officinalis L. (Tejada \& Gonzalez, 2003), chicory, Cichorium intybus L. (Valdrighi et al., 1996), common bean, Phaseolus vulgaris L. (Silva et al., 2016), corn, Zea mays L. (Rodrigues et al., 2017), grapevine, Vitis vinifera L. (Ribeiro et al., 2017), pepper, Capsicum annuum L. (Arancon et al., 2003), soybean, Glycine $\max ($ L.) Merr. (Santos et al., 2017), sugarcane, Saccharum spp. (Civiero et al., 2014), and tomato, Solanum lycopersicum L. (Bernardes et al., 2011). However, there are several limitations to the use of these biostimulants, such as the actual effects of these substances on plants, the required concentration for each species in the condition in which it is cultivated and the ideal time and forms of application.

Currently, there are several sources for biostimulant products, for instance: (i) seaweed extracts, which increase plant germination, growth and yield, as well as increasing biotic and abiotic stress resistance (Khan et al., 2009; 
Craigie, 2011; Mattner et al., 2013); (ii) microbiological inoculants, including mainly arbuscular mycorrhizal free-living bacteria and fungi that can be isolated from the soil, plants, plant residues, water and manure (Berg, 2009; Dodd \& Ruiz-Lozano, 2012); (iii) protein hydrolysates, which consist of a mixture of peptides and amino acids obtained by a variety of animal or vegetable residues (De Lucia \& Vecchietti, 2012; Grabowska et al., 2012; Ertani et al., 2013); and (iv) humic and fulvic acids (Calvo et al., 2014; du Jardin, 2015).

Humic acids (HA) are the most stable reactive fraction of humic substances (HS), containing plant hormones such as auxins, which promote cell stretching, root growth and nutrient absorption, leading to plant growth and development (Calvo et al., 2014). Due to these characteristics, they can be used as biostimulants in increasing lettuce (Lactuca sativa L.) yields (Façanha et al., 2002). The application of HA induces the formation of lateral roots and at the cellular level promotes an increase in the activity and quantity of proton pumps in the biological membranes, making them more efficient in nutrient transport (Baldotto et al., 2011; Canellas \& Olivares, 2014). The influence of HA on the production and quality of lettuce seedlings is still poorly understood, however, studies by Bezerra et al. (2007), Rodrigues (2013), and Santos et al. (2018) have demonstrated positive effects of $\mathrm{HA}$ as a biostimulant on the development and quality of lettuce seedlings.

Associated to HA an alternative that can promote improvement in the quality of lettuce seedlings is the exogenous application of amino acids and vitamins. Amino acids act as activators of physiological metabolism, which can increase the percentage of germination, yield, produce stronger roots and more vigorous plants (Ludwig et al., 2011). Among the amino acids, glycine, in addition to forming proteins, also participates directly in nitrogen metabolism (Stitt et al., 2002). Proline acts as an important cofactor for the maintenance of water balance within the cell, leading to cell elongation as the turgor of cells increases (Goulart et al., 2011).

Unlike amino acids, the main action of vitamins is as an enzyme cofactor (vitamin B1 or thiamine), oxidation-reduction reactions through FAD coenzymes (vitamin B2 or riboflavin), amino acids synthesis (vitamin B1, B2), and germination of pollen grains (vitamin A, B1, B2) (Sinha, 2004). Vitamins are involved in increasing the biochemical reactions efficiency, nutrient assimilation and efficacy of agricultural pesticides (Floss \& Floss, 2007). However, the effect of exogenous application of vitamins is still poorly understood, especially in lettuce cultivation.

In other crops, as common bean, vitamin applications in the plant development did not affected the percentage of germination and productivity (Castro \& Boaretto, 2001). In contrast, positive results were described by Aires et al. (2007), who observed an increase in castor bean, Ricinus communis L., germination as a result of vitamins and carbon sources.

Lettuce is the most abundant and consumed salad crop in Brazil and in the world, corresponding to $11 \%$ of the Brazilian vegetable production, with about 4.9 million metric tons (Blind \& Silva Filho, 2015). However, the success in the cultivation of this vegetable depends mainly on the use of quality seedlings, corresponding to about $60 \%$ of the success of the crop, due to the greater adaptive capacity after transplanting.

Research has been conducted with olive plants to develop biostimulant techniques that will maximize crop production (Izidório et al., 2015). And, although there is a growing interest and use of biostimulants by growers, research documenting biosimulants impact on lettuce development remain insufficient (Vavrina, 2014). Although there are indications that combining the use of humic acids, amino acids, and vitamins has a potential to benefit plant growth, there is limited research documenting their impact on seedling lettuce development and the ideal concentrations. Therefore, the aim of this research was to evaluate the effect of humic acids, amino acids, and vitamins on the morphology and quality of lettuce seedlings.

\section{Material and Methods}

\subsection{Seedling Production, Growth Conditions, and Treatments}

Two experiments (A and B) were conducted simultaneously under greenhouse conditions at Experimental Field of Universidade Federal do Tocantins (UFT), Campus Gurupi (11 $43^{\prime} 45^{\prime \prime} \mathrm{S}$ and $\left.49^{\circ} 04^{\prime} 07^{\prime \prime} \mathrm{W}\right)$, located in the southern region of the Tocantins state at an altitude of $280 \mathrm{~m}$. According to the Köppen climate classification, the regional climate is of the B1wA'a' moist type with moderate water deficiency (Alvares et al., 2013). The average annual temperature is $29.5^{\circ} \mathrm{C}$, with an average annual precipitation of $1804 \mathrm{~mm}$.

The lettuce seedlings were produced in a greenhouse with plastic cover, $50 \%$ shade side panels, in multicellular trays of 128 cells each, filled with commercial substrate (Tropstrato ${ }^{\circledR}$ ) mixed with 1:1 carbonized rice husk. Five seeds were placed in the center of each cell at a depth of $5 \mathrm{~mm}$. Seedling thinning was performed seven days after germination (DAG), maintaining one plant per cell. The experiment consisted of production system of lettuce seedlings, cv. Elba, with the application of humic acids (HA) supplemented with sources, and levels of 
vitamins and amino acids. The seedling trays were irrigated water daily until the final stage of seedling formation.

The HA source for this research was extracted from alternative organic compound, of cattle rumen residue from municipal slaughterhouse, and was quantitatively characterized as: $10 \mathrm{~g} \mathrm{~kg}^{-1}$ nitrogen (N) and $25 \mathrm{~g} \mathrm{~kg}^{-1}$ organic carbon (C). $\mathrm{C}$ and $\mathrm{N}$ levels of HA were determined according to Mendonça and Matos (2005).

Experiment A: was conducted in a completely randomized design with four replicates and constituted by 16 treatments in factorial design $3 \times 5+1$, factor 1 included three amino acids (betaine, glycine, and proline), combined with HA $\left(22 \mathrm{ml} \mathrm{L}^{-1}\right)$, and factor 2 included five concentrations of amino acids $(0,0.5,1.0,1.5$, and 2.0 $\left.\mathrm{g} \mathrm{L}^{-1}\right)$, plus an additional treatment which did not have either HA or amino acid applications.

Experiment $B$ : was conducted in a completely randomized design with four replicates, consisted of 21 treatments, in a $4 \times 5+1$ factorial design. The first factor was the $\mathrm{HA}\left(22 \mathrm{ml} \mathrm{L}^{-1}\right)$ enriched with four different vitamins (A, E, $\mathrm{B} 1$, and B2). The second factor was composed of five vitamin concentrations $\left(0,0.5,1.0,1.5\right.$, and $\left.2.0 \mathrm{~g} \mathrm{~L}^{-1}\right)$. And the last treatment, the control, did not receive HA or vitamin applications.

The experiment treatments were applied to the seedling leaves at 7 and 14 days after emergence (DAE) with a manual sprayer, applying approximately $3.0 \mathrm{~mL} \mathrm{plant}^{-1}$. The HA concentration used in this research was based on research results described by Rodrigues (2013) and Santos (2013). Biometrics parameters of lettuce seedlings were evaluated at 21 days after sowing.

\subsection{Biometric Parameters, Nitrogen Determination, and Quality of Seedlings}

To determine the shoot dry mass the material was oven dried at $60{ }^{\circ} \mathrm{C}$ for 72 hours. After drying, the shoot was weighed on an electronic analytical balance $(0.0001 \mathrm{~g})$, The number of leaves was determined by counting, excluding cotyledons. Plant height was measured from base to the end of the seedling using a ruler graduated in $\mathrm{mm}$. Stem diameter was determined by measuring the medial part of the stem with a digital caliper $(\mathrm{mm})$. Root dry mass was determined after the roots were oven dried at $60{ }^{\circ} \mathrm{C}$ for 72 hours. After drying, the roots were weighed in on electronic analytical balance $(0.0001 \mathrm{~g})$. Root length was measured from the base of the seedling to the tip of the longest root, using a ruler graduated in $\mathrm{mm}$.

The total $\mathrm{N}$ content in leaves and roots were extracted through acid digestion and determined according to the Kjeldahl method (Bremner \& Mulvaney, 1982).

The Dickson Quality Index (DQI) was calculated by the following formula, Dickson et al. (1960):

$$
\mathrm{DQI}=\frac{\mathrm{TDM}}{\left(\frac{\mathrm{PH}}{\mathrm{SD}}\right)+\left(\frac{\mathrm{DMS}}{\mathrm{DMR}}\right)}
$$

where, DQI: Dickson Quality Index; TDM: total dry mass(g); PH: plant height (cm); SD: stem diameter (cm); DMS: dry mass of shoot (g); DMR: dry mass of roots (g).

\subsection{Statistical Analysis}

The data were subjected to analysis of variance and regression through the Sigma Plot $10 ®$ program. The regression models were chosen based on the significance of the coefficients of the regression equation and the coefficient of determination, using 1 and $5 \%$ of probability.

\section{Results}

The addition of increasing levels of amino acids or vitamins associated with HA resulted in differences in respect to lettuce seedling development. For dry mass of shoot and number of leaves, the increase in concentrations promoted a linear increase, showing that the variables would still respond to the application of concentrations higher than $2 \mathrm{~g} \mathrm{~L}^{-1}$, regardless of the amino acid source (Figures 1a and 1c). According to the regression equations, for each $0.5 \mathrm{~g} \mathrm{~L}^{-1}$ of amino acids added to the HA there was an increase of $0.0056,0.0068$ and 0.0044 $\mathrm{g}$ per plant in the dry mass of shoot and $0.2,0.1$ and 0.05 in number of leaves with betaine, glycine and proline, respectively. For the dry mass of shoot, the concentration of $2 \mathrm{~g} \mathrm{~L}^{-1}$ of glycine was greater when compared to the control (Figure 1a), while for leaf numbers the best result was obtained by the application of betaine, in which the maximum level of $2.0 \mathrm{~g} \mathrm{~L}^{-1}$ produced approximately 3.5 leaves (Figure 1c), doubling the number of leaves in relation to the control.

In relation to the addition of vitamins levels, and the impacts to the parameter dry mass of shoot, was observed the quadratic effect for the vitamins $\mathrm{E}$ and $\mathrm{B}$, exponential effect for application of vitamin B1 and linear reduction for vitamin A application (Figure 1b). For the number of leaves, there was a quadratic response due to the addition of vitamins $\mathrm{E}, \mathrm{B} 1$ and $\mathrm{B} 2$, while the addition of vitamin A promoted a linear reduction in the number 
of leaves (Figure 1d). The application of vitamin B2 in the concentration of $2 \mathrm{~g} \mathrm{~L}^{-1}$ promoted a $71 \%$ increase in this parameter when compared to the control.
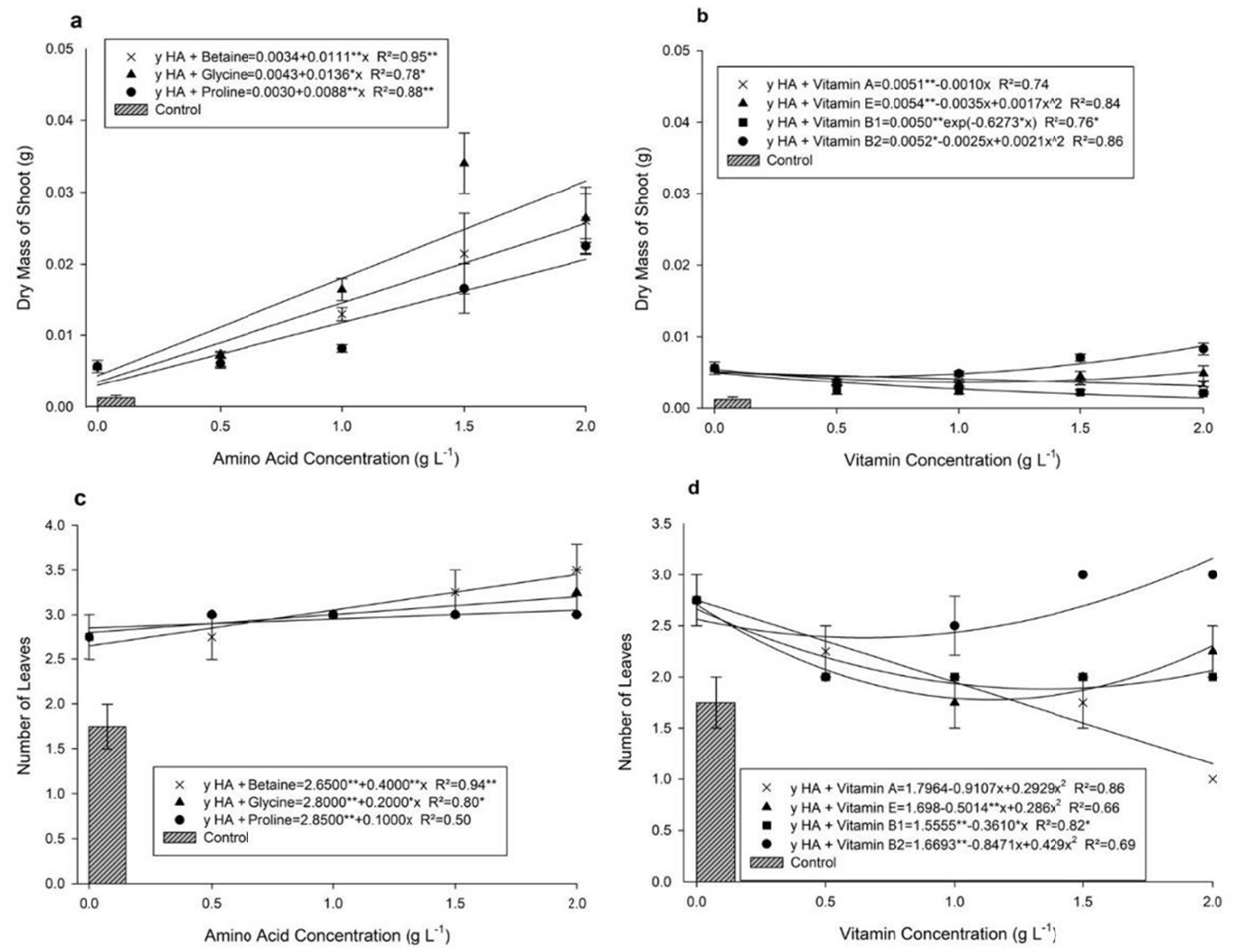

Figure 1. Dry mass of shoot (a), and number of leaves (c) in function of humic acid (HA) and amino acid concentration $\left(\mathrm{g} \mathrm{L}^{-1}\right)$, dry mass of shoot $(\mathrm{b})$, and number of leaves $(\mathrm{d})$ in function of HA and vitamin concentration $\left(\mathrm{g} \mathrm{L}^{-1}\right)$

A better statistical fit was observed for plant height as a function of increasing levels of amino acids with the application of glycine $2.0 \mathrm{~g} \mathrm{~L}^{-1}$, which resulted in $3.05 \mathrm{~cm}$ plant height, approximately $2 \mathrm{~cm}$ greaterr than the control (Figure 2a). It was observed that the increase in glycine concentration promoted a quadratic response regarding stem diameter, whereas betaine and proline promoted a linear growth in the stem diameter. Therefore, inferring that this variable will still respond to concentrations greater than $2 \mathrm{~g} \mathrm{~L}^{-1}$ (Figure 2c). The application of betaine and proline, both at the concentration $2 \mathrm{~g} \mathrm{~L}^{-1}$, produced a stem diameter of $1.24 \mathrm{~mm}$, resulting in a $51 \%$ increase in relation to the control.

It was observed that the increase of vitamin $\mathrm{A}$ and $\mathrm{E}$ concentration resulted in a quadratic response in plant height, while the increase of vitamins B1 and B2 promoted a linear reduction in plant height (Figure 2b). Therefore, with every $0.5 \mathrm{~g} \mathrm{~L}^{-1}$ of vitamins B1 and B2 added to the HA, there is a reduction in height of 0.18 and $0.42 \mathrm{~cm}$ per plant, respectively. The best plant height performance with biostimulant use with the addition of vitamins was obtained with vitamin $\mathrm{E}$ in the concentration of $2 \mathrm{~g} \mathrm{~L}^{-1}, 1.77 \mathrm{~cm}$. There was a quadratic effect involving stem diameter with vitamin $\mathrm{B} 2$ and a linear reduction with increasing concentrations of vitamins $\mathrm{A}$, $\mathrm{E}$ and B1, for each $0.5 \mathrm{~g} \mathrm{~L}^{-1}$ of vitamin added in the HA (Figure 2d). The best stem diameter was obtained with the application of HA without the addition of vitamins, $32 \%$ greater than the control, without application of vitamins and HA. 

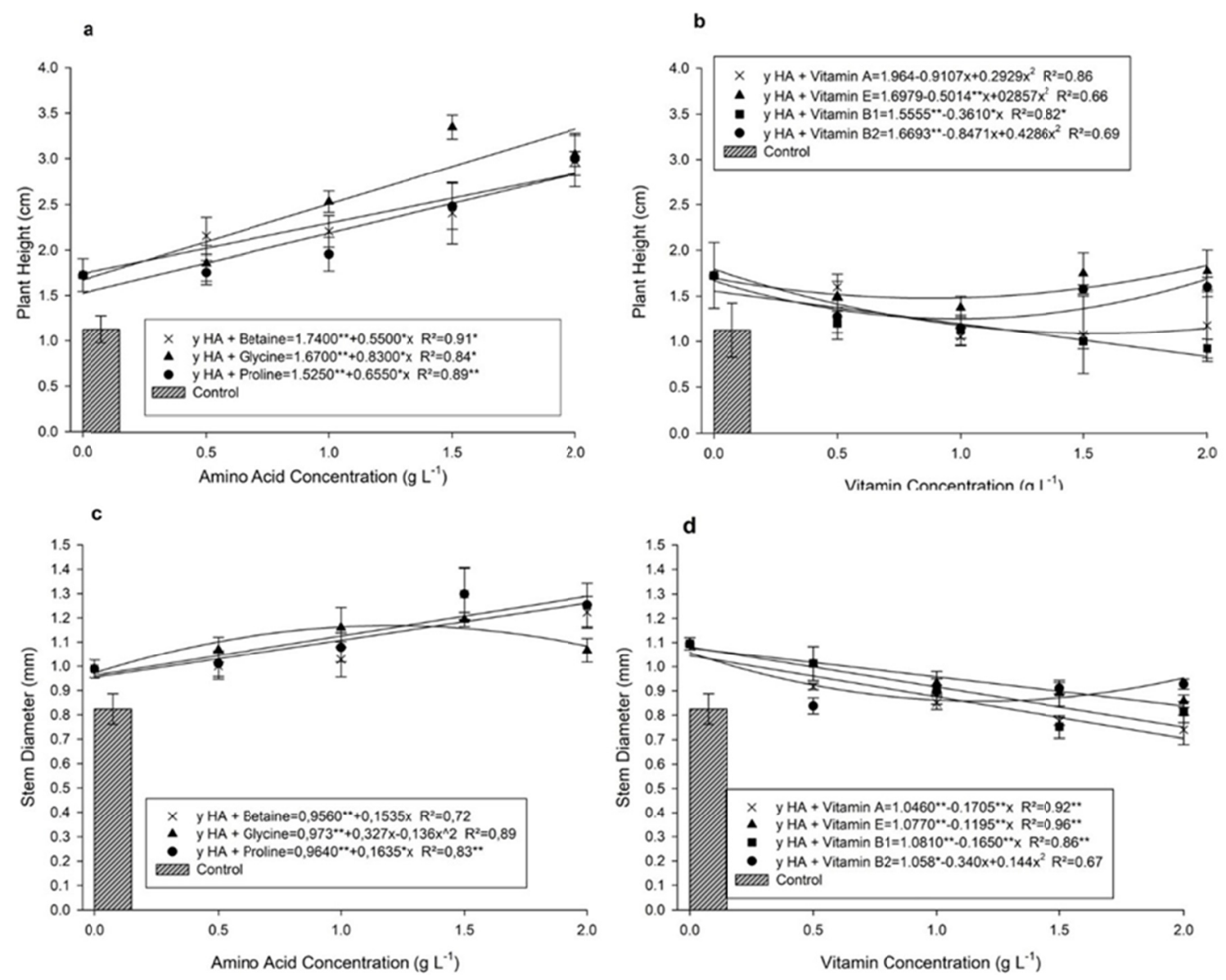

Figure 2. Plant height (a), and stem diameter (c) in function of Humic Acid (HA) and amino acid concentration $\left(\mathrm{g} \mathrm{L}^{-1}\right)$, plant height (b), and stem diameter (d) in function of HA and vitamin concentration $\left(\mathrm{g} \mathrm{L}^{-1}\right)$

The increase in the concentration of amino acids promoted a linear increase in dry root mass (Figure 3a). The plants responded positively at levels above $2 \mathrm{~g} \mathrm{~L}^{-1}$, regardless of the amino acid source used. The best dry root results were obtained with the application of betaine at $2 \mathrm{~g} \mathrm{~L}^{-1}$, resulting in $0.0158 \mathrm{~g}$ per plant, corresponding to a 14-fold increase when compared to the control. As for root length, it was found that the increase in the concentration of the amino acids betaine and glycine promoted a quadratic response, while the addition of proline resulted in a linear increase, showing that this characteristic will still respond to proline levels higher than $2 \mathrm{~g} \mathrm{~L}^{-1}$ (Figure 3c). The maximum efficiency of the amino acids betaine, glycine and proline was with 1.43, 1.47 , and $2 \mathrm{~g} \mathrm{~L}^{-1}$ resulting in, $12.16,12.62$, and $11.54 \mathrm{~cm}$, respectively, corresponding to an average increase of $69 \%$ in relation to the control.

The increase of vitamin concentrations for dry root mass promotes a quadratic effect for vitamins $\mathrm{E}$ and B2. Yet, the increase in the concentration of vitamins A and B1 linearly reduced this variable (Figure 3b). This means that for every $0.5 \mathrm{~g} \mathrm{~L}^{-1}$ of vitamin A and B1 added in the HA there was a reduction of 0.0015 and $0.0006 \mathrm{~g}$ of dry mass of roots per plant, respectively. In relation to the root length, the increase of vitamin E and B2 concentrations promoted a quadratic effect. The application of increasing levels of vitamins A and B1 promoted a linear reduction in root length and for each $0.5 \mathrm{~g} \mathrm{~L}^{-1}$ of vitamins added in the HA the reduction was 0.492 and $0.335 \mathrm{~cm}$ per plant, respectively (Figure 3d). The application of vitamins, regardless of the source and concentration used, did not differ from the control in root dry mass, however, an increase of $27.8 \%$ in root length was observed when compared to the control with an application of vitamin B2 in the concentration of $2.0 \mathrm{~g} \mathrm{~L}^{-1}$, resulting in $9.18 \mathrm{~cm}$ roots. 

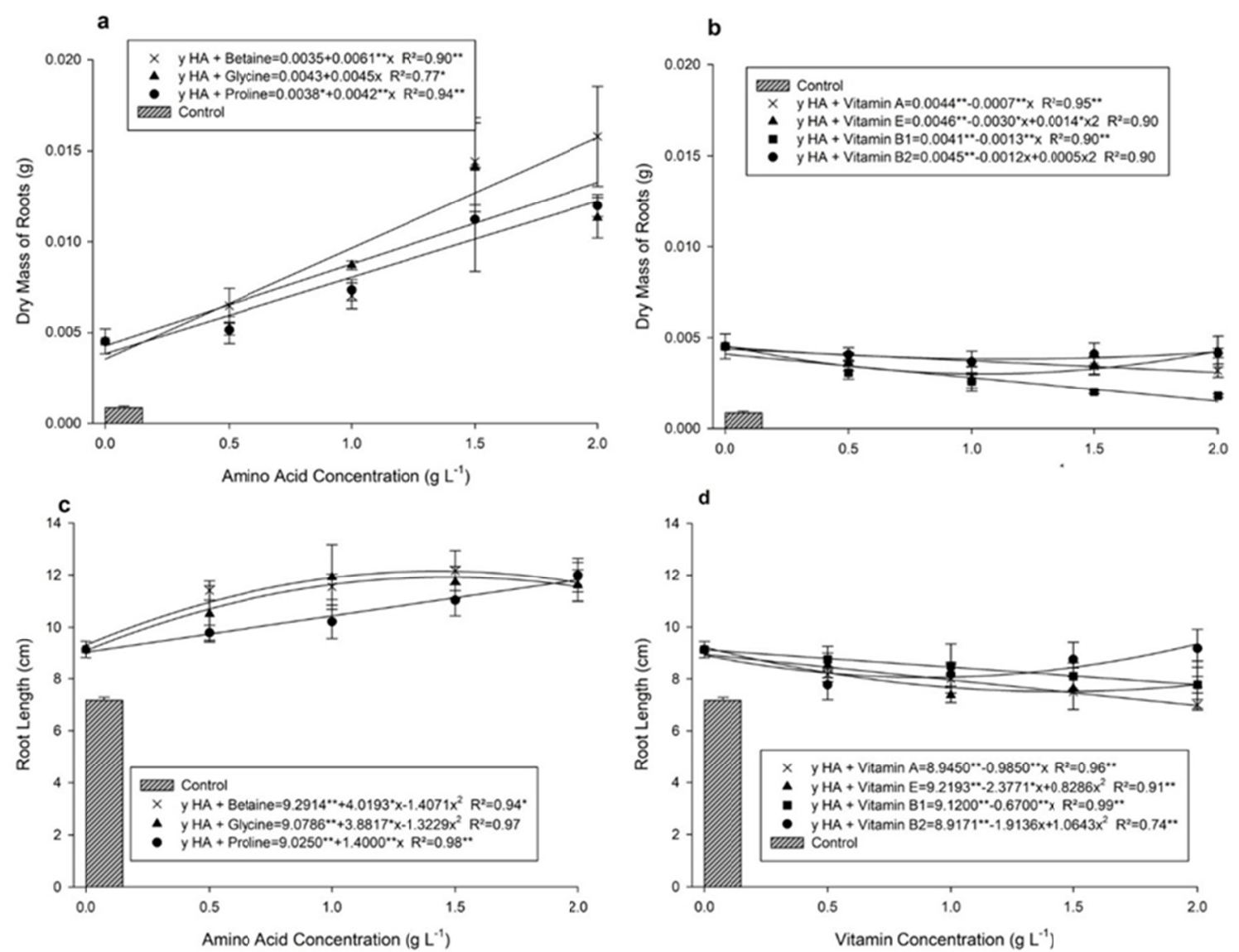

Figure 3. Dry mass of roots (a), and root lenght (c) in function of Humic Acid (HA) and amino acid concentration $\left(\mathrm{g} \mathrm{L}^{-1}\right)$, dry mass of roots (b), and root lenght (d) in function of HA and vitamin concentration $\left(\mathrm{g} \mathrm{L}^{-1}\right)$

A significant increase in leaf nitrogen content was observed as a function of the amino acids applied, resulting in a quadratic effect, and a concentration of $1.20 \mathrm{~g} \mathrm{~L}^{-1}$ of proline, a $64 \%$ greater than the control (Figure 4a). A proline concentration of $1.27 \mathrm{~g} \mathrm{~L}^{-1}$ produced greatest nitrogen content in the roots (Figure $4 \mathrm{c}$ ).

The increase vitamin A, E and B1 concentations resulted in quadratic effect about leaf nitrogen content (Figure 4b). In contrast, vitamin B2 concentration promoted a linear increase, corresponding to an increase of 1.5 times compared to the control. For the nitrogen content of the roots, the best performance was also obtained with the application of vitamin B2 (Figure 4d). 

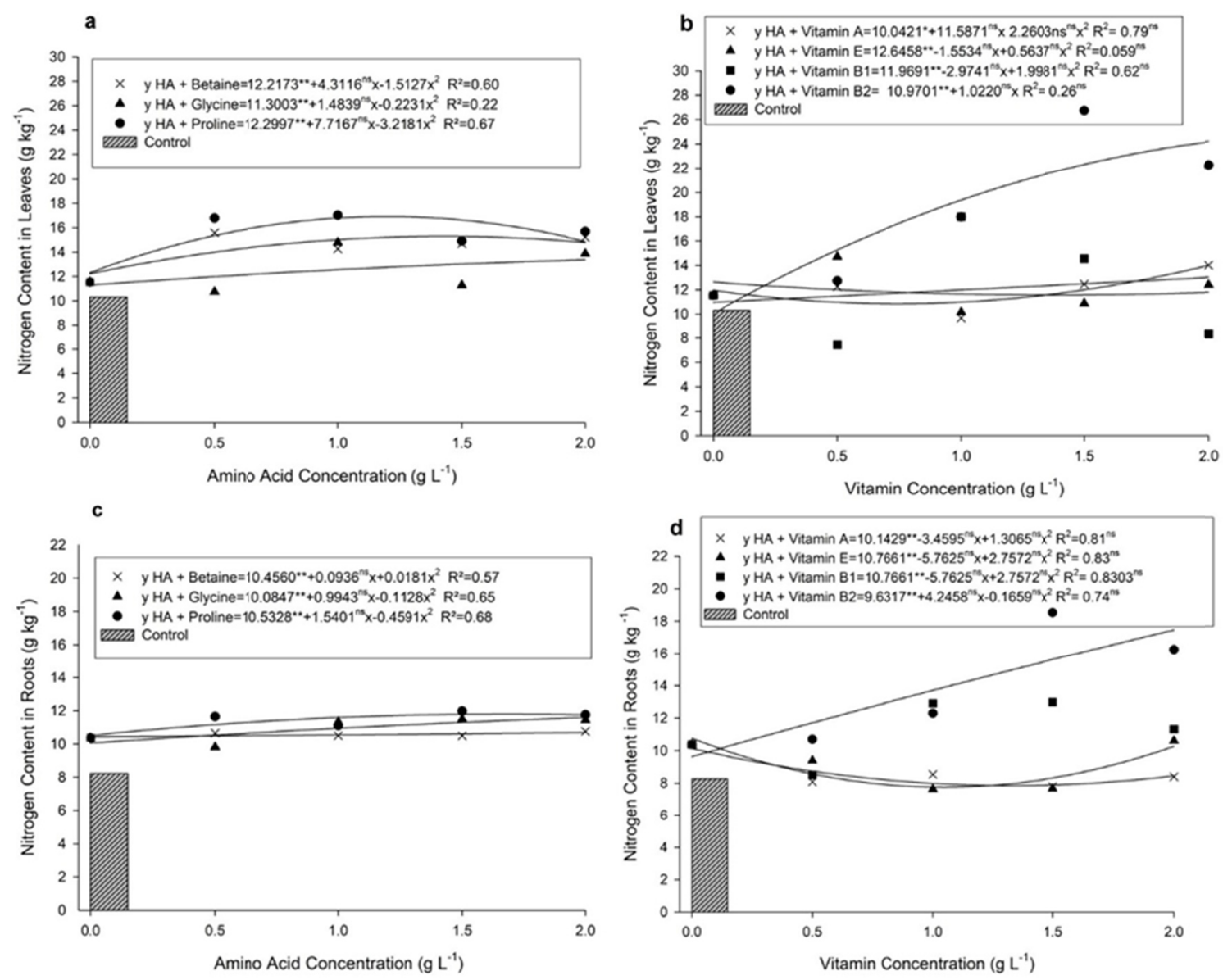

Figure 4. Nitrogen content in Leaves (a), and in roots (c) in function of Humic Acid (HA) and amino acid concentration $\left(\mathrm{g} \mathrm{L}^{-1}\right)$, nitrogen content in leaves (b), and in roots (d) in function of HA and vitamin concentration $\left(\mathrm{g} \mathrm{L}^{-1}\right)$

It was observed that the addition of amino acids together with the HA promoted linear increases in the seedling quality (Figure 5a). The optimum seedling quality was obtained with the application of the amino acids in the concentration of $2.0 \mathrm{~g} \mathrm{~L}^{-1}$, reaching indexes of $0.0101,0.0079$, and 0.0080 for betaine, glycine and proline, respectively. These results showed no significant difference between them, however, when compared with the control, DQI $=0.0008$, there was a large increase in this lettuce seedling variable.

There was a quadratic effect on seedling quality when vitamins A, E, or B2 were added to HA, but a linear reduction when adding vitamin B1 (Figure 5b). There were no significant differences among the levels and vitamin with a DQI average of 0.0027 lower than the control. 

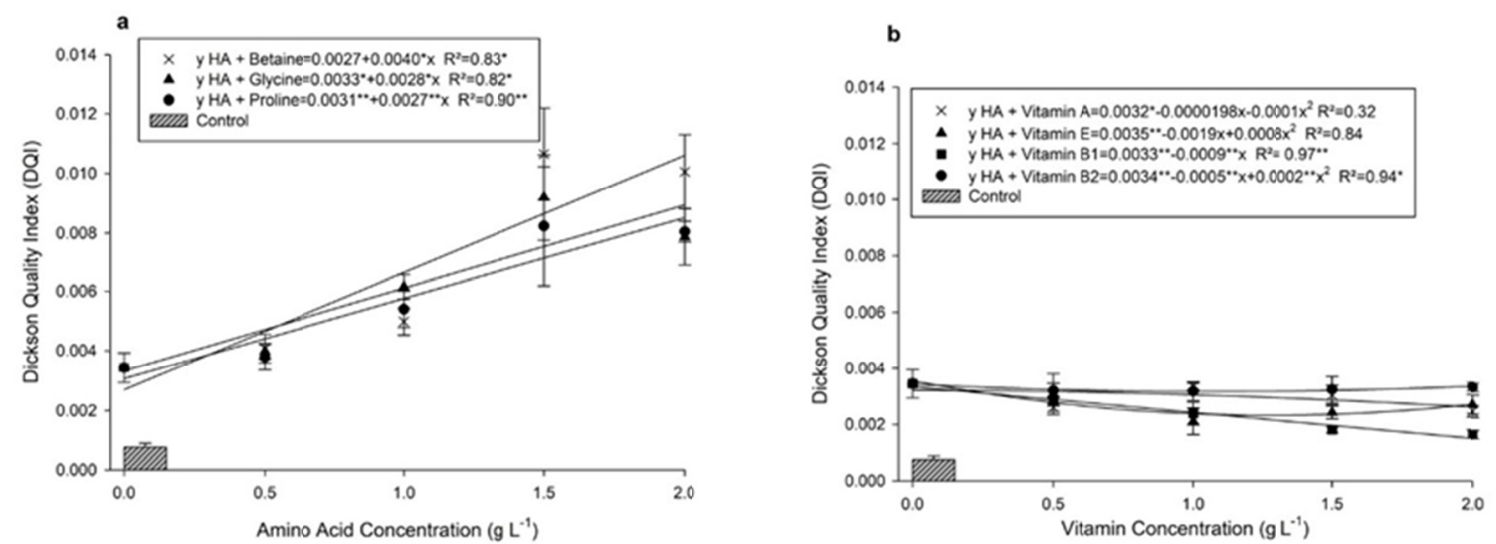

Figure 5. Dickson quality index in function of Humic Acid (HA) and amino acid concentration $\left(\mathrm{g} \mathrm{L}^{-1}\right)(\mathrm{a})$, and in function of $\mathrm{HA}$ and vitamin concentration $\left(\mathrm{g} \mathrm{L}^{-1}\right)(\mathrm{b})$

\section{Discussion}

Silva et al. (2000a) also obverved a positive impact of HA on lettuce plant development showing a $257 \%$ increase in shoot dry weight. Hernandez et al. (2013) observed that lettuce plants submitted to HS concentrations presented a higher number of leaves and a reduction in the production cycle. Moreover, Rodrigues (2013) reported greater lettuce ssedling development and root production with the applications of HS and amino acids. The exogenous application of glycine can increase the production of proteins, chlorophylls, catalase and phytochrome, and participate in the metabolism of nitrogen (Ashraf \& Foolad, 2007). While proline acts as an important cofactor for the maintenance of potential water balance within the cell, leading to cell elongation as cell turgor increases (Goulart et al., 2011). The increase in dry mass can be explained by the rapid metabolization of the exogenously applied amino acids, thus increasing the enzymatic activities regarding the metabolism of nutrients such as nitrogen, generating a greater accumulation of photoassimilates.

Increasing the rate lettuce seedling development due to the use of HS and amino acids is reported by Silva et al. (2000a). These compounds can influence the substrate fertility by releasing nutrients, improving the physical and biological conditions, and the production of physiologically active substances. These substances can also directly promote changes in plants and modify their physiology, morphology, nutrient absorption capacity, as well as plant height and stem diameter (Rodrigues, 2013; Santos, 2013).

Bezerra et al. (2007) evaluated the combination of commercial fertilizers based on HS in lettuce plants, and observed that as the product concentration increased, there was an increase in root dry mass $(45.70 \%)$ and in root length $(9.92 \mathrm{~cm})$. Also, positive results for the application of commercial products based on HS and alternative sources, also from cattle rumen residue, are reported by Santos (2013), and they verified that for both (commercial and alternative) sources, there were significant increases in the root development of lettuce seedlings.

The greatest reported benefit of HA to plants is related to root system development. For example, increased formation of o lateral roots (Canellas et al., 2002; Baldotto et al., 2011; Mora et al., 2012), the formation of adventitious roots (Baldotto et al., 2012; L. E. B. Baldotto \& M. A. Baldotto, 2014), root lengthening (Silva et al., 2000b), and the formation of root hairs (Canellas et al., 2011; Silva et al., 2011). According to Casimiro et al. (2001), the increase in the lateral root induction is directly related to the auxin, since it acts in the initial stages of the formation of the root primordium, activating the division of the pericycle cells. Canellas et al. (2011) state that HA can provide plants with molecules with auxin-like activity and thus directly influence root development. In contrast, it was observed that this effect of HA together with the vitamins in the root development (root length and dry mass of roots) of the seedlings was reduced with the interaction of HA mainly with vitamins A and B1 (Figures 1B and 1C).

Santos (2013) obtained positive results in root development (dry mass of roots and root length) of lettuce seedlings with application of alternative biostimulants based on HS, against commercial products. However, Pereira et al. (1983) observed that there was no significant difference in the production of branches and roots of cassava under the application of four bioregulators (gibberellic acid, naphthalene acetic acid, vitamin B1 and indoleacetic acid) when compared with each other and with the control treatments. 
The development of a better root system provides seedlings with more ideal conditions for nutrient and water absorption (Reis et al., 2012). If a short period of water deficiency occurs, there is a greater probability that a plant will survice when it poccesses an enhanced root system. In this sense, it can be inferred that the seedlings produced with application of humic acids would have greater ability to establishment in the field, due to the greater root development.

Positive results in the DQI of lettuce seedlings with the use of amino acids were also found by Santos (2013), who reports that the application of products based on HA promote better quality indexes then the control. According to Fonseca et al. (2002), and Batista et al. (2014), DQI considers the robustness and the balance of biomass distribution in the seedlings, considering the results of several important parameters used for quality evaluation, and, thereby, being a good indicator of seedling quality. Thus, it can be said that the seedlings produced under the application of fertilizer composed of HA would produce more robust seedlings with a greater chance of survival after transplantation to the final location.

\section{Conclusion}

The use of HA in the presence or absence of other compounds, such as amino acids and vitamins, demonstrate positive changes in the development of lettuce seedlings, improving aspects such as nutrient absorption and morphology. In this way the use of HA, vitamins, and amino acids can contribute to the production of more robust lettuce seedlings, increasing the survival chances after transplanting. However, high concentrations of these compounds can cause negative effects on plant development; thus, further research is needed to clarify the effects of these substances on plants, as well as to calibrate the ideal level for each species in the condition in which it is grown.

\section{References}

Aires, P. S. R., Carvalho, J. M. F. C., Pimentel, N. W., \& Silva, H. (2007). Effect of the vitamin concentration and the carbon sources in the multiple shoots induction of castor using genotype BRS Nordestina. Revista Bioterra, 7(2), 1-5.

Alvares, C. A., Stape, J. L., Sentelhas, P. C., Goncalves, J. L. M., \& Sparovek, G. (2013). Koppen's climate classification map for Brazil. Meteorologische Zeitschrift, 22, 711-728. https://doi.org/10.1127/0941-2948/ 2013/0507

Ashraf, M., \& Foolad, M. R. (2007). Roles of glycine betaine and proline in improving plant abiotic stress resistance. Environmental and Experimental Botany, 59(2), 206-216. https://doi.org/10.1016/j.envexpbot. 2005.12.006

Arancon, N. Q., Lee, S., Edwards, C. A., \& Atiyeh, R. (2003). Effect of humic acids derived from cattle, food and paper-waste vermicomposting on growth of greenhouse plants. Pedobiologia, 47(5-6), 741-744. https://doi.org/10.1078/0031-4056-00253

Baldotto, L. E. B., \& Baldotto, M. A. (2014). Adventitious rooting on the Brazilian red-cloak and sanchezia after application of indole-butyric and humic acids. Horticultura Brasileira, 32(4), 426-431. https://doi.org/ $10.1590 / \mathrm{S} 0102-053620140000400010$

Baldotto, L. E. B., Baldotto, M. A., Soares, R. R., Martinez, H. E. P., \& Venegas, V. H. A. (2012). Adventitious rooting in cuttings of croton and hibiscus in response to indolbutyric acid and humic acid. Revista Ceres, 59(4), 476-483. https://doi.org/10.1590/S0034-737X2012000400007

Baldotto, L. E. B., Olivares, F. L., \& Bressan-Smith R. (2011). Structural interaction between GFP-labeled diazotrophic endophytic bacterium Herbaspirillum seropedicae RAM10 and pineapple plantlets 'Vitória'. Brazilian Journal of Microbiology, 42(1), 114-125. https://doi.org/10.1590/S1517-83822011000100015

Baldotto, M. A., Rosa, R. C. C., Canellas, L. P., Rangel, T. P., Salomão, M. S. M. B., \& Rezende, C. E. (2011). Oxidation capacity as an index of organic matter stability from sediments of the Paraíba do Sul river-estuarine gradient. Química Nova, 34(6), 973-978. https://doi.org/10.1590/S0100-4042201100 0600011

Batista, R. O., Martinez, M. A., Paiva, H. N., Batista, R. O., \& Cecon, P. R. (2014). The effect of swine wastewater in the development and quality of seedling of Eucalyptus urophylla. Ciencia Florestal, 24(1), 127-135.

Berg, G. (2009). Plant-microbe interactions promoting plant growth and health: Perspectives for controlled use of microorganisms in agriculture. Applied Microbiology and Biotechnology, 84(1), 11-18. https://doi.org/ $10.1007 / \mathrm{s} 00253-009-2092-7$ 
Bernardes, J. M., Reis, J. M. R., \& Rodrigues, J. F. (2011). Effect of humic substance application on tomato seedlings. Global Science and Technology, 04(3), 92-99.

Bezerra, P. S. G., Grangeiro, L. C., Negreiros, M. Z., \& Medeiros, J. F. (2007). Use of biostimulants on the production of lettuce seedlings. Cientifica, 35(1), 46-50.

Blind, A. D., \& Silva Filho, D. F. (2015). Productivity performance in cultivars of crisphead lettuce in the dry season of Central Amazonia. Bioscience Journal, 31(2), 404-414.

Bremner, J. M., \& Mulvaney, C. S. (1982). Nitrogen-Total. In A. L. Page (Ed.), Methods of Soil Analysis. Part 2. Chemical and Microbiological Properties (pp. 595-624). Madison, WI: American Society of Agronomy.

Calvo, P., Nelson, P., \& Kloepper, J. W. (2014). Agricultural uses of plant biostimulants. Plant and Soil, 383(1-2), 3-41. https://doi.org/10.1007/s11104-014-2131-8

Canellas, L. P., Dantas, D. J., Aguiar, N. O., Peres, L. E. P., Zsogon, A., Olivares, F. L., ... Piccolo, A. (2011). Probing the hormonal activity of fractionated molecular humic components in tomato auxin mutants. Annals of Applied Biology, 159, 202-211. https://doi.org/10.1111/j.1744-7348.2011.00487.x

Canellas, L. P., \& Olivares, F. L. (2014). Physiological responses to humic substances as plant growth promoter. Chemical and Biological Technologies in Agriculture, 1(3), 1-11. https://doi.org/10.1186/2196-5641-1-3

Canellas, L. P., Olivares, F. L., Okorokova-Facanha, A. L., \& Façanha, A. R. (2002). Humic acids isolated from earthworm compost enhance root elongation, lateral root emergence, and plasma membrane $\mathrm{H}^{+}$-ATPase activity in maize roots. Plant Physiology, 130(4), 1951-1957. https://doi.org/10.1104/pp.007088

Casimiro, I., Marchant, A., Bhalerao, R. P., Beeckman, T., Dhooge, S., Swarup, R., ... Bennett, M. (2001). Auxin transport promotes Arabidopsis lateral root initiation. The Plant Cell, 13, 843-852. https://oi.org/10.1105/ tpc.13.4.843

Castro, A. M. C., \& Boaretto, A. E. (2001). Foliar fertilization of bean with nutrients, B1 vitamin and methionine. Scientia Agraria, 2(1-2), 1-5.

Civiero, J. C., Daros, E., Melo, L. J. O. T., Weber, H., Mógor, A. F., \& Figueiredo, G. G. O. (2014). Application of humic substance and L-glutamic amino acid in different sizes of 1-bud sett of sugarcane. Revista de Ciencias Agrarias, 37(3), 340-347

Craigie, J. S. (2011). Seaweed extract stimuli in plant science and agriculture. Journal of Applied Phycology, 23(3), 371-393. https://doi.org/10.1007/s10811-010-9560-4

De Lucia, B., \& Vecchietti, L. (2012). Type of bio-stimulant and application method effects on stem quality and root systemgrowth in L.A. Lily. European Journal of Horticultural Science, 77(1), 10-15.

Dickson, A., Leaf, A. L., \& Hosner, J. F. (1960). Quality appraisal of white spruce and white pine seedling stock in nurseries. Forest Chronicle, 36, 10-13. https://doi.org/10.5558/tfc36010-1

Dodd, I. C., \& Ruiz-Lozano, J. M. (2012). Microbial enhancement of crop resource use efficiency. Current Opinion in Biotechnology, 23(2), 236-242. https://doi.org/10.1016/j.copbio.2011.09.005

du Jardin, P. (2015). Plant biostimulants: Definition, concept, main categories and regulation. Scientia Horticulturae, 196, 3-14. https://doi.org/10.1016/j.scienta.2015.09.021

Ertani, A., Schiavon, M., Muscolo, A., \& Nardi, S. (2013). Alfalfa plantderived biostimulant stimulate short-term growth of salt stressed Zea mays L. plants. Plant and Soil, 364(1-2), 145-158. https://doi.org/10.1007/ s11104-012-1335-z

Façanha, A. R., Façanha, A. L. O., Olivares, F. L., Guridi, F., Santos, G. A., Velloso, A. C. X, ... Canellas, L. P. (2002). Humic acids bioactivity: Effects on root development and on the plasma membrane proton pump. Pesquisa Agropecuária Brasileira, 37(9), 1301-1310. https://doi.org/10.1590/S0100-204X2002000900014

Floss, E. L., \& Floss, L. G. (2007). Fertilizantes organominerais de última geracao: Funcoes fisiológicas e uso na agricultura. Revista Plantio Direto, 100.

Fonseca, E. P., Valéri, S. V., Miglioranza, E., Fonseca, N. A. N., \& Couto, L. (2002). Target seedlings of Trema micranta (L.) Blume grown under different periods of shading. Revista Árvore, 26, 515-523. https://doi.org/10.1590/S0100-67622002000400015

Goulart, P. B., Xavier, A., \& Dias, J. M. M. (2011). Effect of cofactors hydroquinone, proline and tryptophane on the rooting of mini-cuttings of Eucalyptus grandis $\times$ E. urophylla clones. Revista Árvore, 35(5), 1017-1026. https://doi.org/10.1590/S0100-67622011000600007 
Grabowska, A., Kunicki, E., Sekara, A., Kalisz, A., \& Wojciechowska, R. (2012). The effect of cultivar and biostimulant treatment on the carrot yield and its quality. Vegetable Crops Research Bulletin, 77(1), 37-48. https://doi.org/10.2478/v10032-012-0014-1

Hernandez, O. L., Huelva, R., Guridi, F., Olivares, F. L., \& Canellas, L. P. (2013). Humates isolated from vermicompost as growth promoter in organic lettuce production. Revista Ciencias Técnicas Agropecuarias, $22(1), 70-75$.

Izidório, T. H. C., Lima, S. F., Vendrusculo, E. P., Ávila, J., \& Alvarez, R. C. F. (2015). Biostimulant foliar application in lettuce after transplanting of seedlings. Journal of Neotropical Agriculture, 2(2), 49-56. https://doi.org/10.32404/rean.v2i2.257

Khan, W., Rayirath, U. P., Subramanian, S., Jithesh, M. N., Rayorath, P., Hodges, D. M., ... Prithiviraj, B. (2009). Seaweed Extracts as Biostimulants of Plant Growth and Development. Journal of Plant Growth Regulation, 28, 386-399. https://doi.org/10.1007/s00344-009-9103-x

Ludwig, M. P., Lucca Filho, O. A., Baudet, L., Dutra, L. M. C., Avelar, S. A. G., \& Crizel, R. L. (2011). Seed quality of stored soybean after coating with amino acid, polymer, fungicide and insecticide. Revista Brasileira de Sementes, 33(3), 395-406. https://doi.org/10.1590/S0101-31222011000300002

Mattner, S. W., Wite, D., Riches, D. A., Porter, I. J., \& Arioli, T. (2013). The effect of kelp extract on seedling establishment of broccoli on contrasting soil types in southern Victoria, Australia. Biological Agriculture \& Horticulture, 29(4), 258-270. https://doi.org/10.1080/01448765.2013.830276

Meirelles, A. F. M., Baldotto, M. A., \& Baldotto, L. E. B. (2017). Productivity of lettuce (Lactuca sativa L.) in response to the application of humic acids and diazotrophic bacteria, under field conditions. Revista Ceres, 64(5), 553-556. https://doi.org/10.1590/0034-737x201764050014

Mendonça, E. S., \& Matos, E. S. (2005). Matéria orgânica do solo: Métodos de análises. Viçosa, Brazil

Mora, V., Baigorri, R., Bacaicoa, E., Zamarreño, A. M., \& García-Mina, J. M. (2012). The humic acid-induced changes in the root concentration of nitric oxide, IAA and ethylene do not explain the changes in root architecture caused by humic acid in cucumber. Environmental and Experimental Botany, 76, 24-32. https://doi.org/10.1016/j.envexpbot.2011.10.001

Pereira, A. S., Lorenzi, J. O., \& Monteiro, D. A. (1983). Growth regulators in cassava production. Bragantia, 43, 673-676.

Reis, B. E., Paiva, H. N., Barros, T. C., Ferreira, A. L., \& Cardoso, W. C. (2012). Growth and seedling quality of Jacarandá-da-bahia in response to potassium and sulfur fertilization. Ciência Florestal, 22(2), 389-396.

Ribeiro, R. F., Lobo, J. T., Cavalcante, I. H. L., Tenreiro, I. G. P., \& Lima, D. D. (2017). Biostimulant on seedling production of grape cv. Crimson Seedless. Scientia Agraria, 18(4), 36-42. https://doi.org/10. 5380/rsa.v18i4.50922

Rodrigues, L. A., Alves, C. Z., Rego, C. H. Q., Silva, T. R. B., \& Silva, J. B. (2017). Humic acid on germination and vigor of corn seeds. Revista Caatinga, 30(1), 149-154. https://doi.org/10.1590/1983-21252017 v30n116rc

Rodrigues, L. U. (2013). Alternative substrates with mixture proportions of rice husk carbonised in quality of tomato seedlings and influence of fractions of humic acids in the production of lettuce seedlings (Unpublished Master's Thesis, Universidade Federal do Tocantins, Gurupi, Brazil).

Santos, A. C. M. (2013). Efficiency of humic acid in the production of lettuce (Lactuca sativa) under high temperature, replacing nitrogen fertilization (Unpublished Master's Thesis, Universidade Federal do Tocantins, Gurupi, Brazil).

Santos, A. C. M., Rodrigues, L. U., Andrade, C. A. O., Carneiro, J. S. S., \& Silva. R. R. (2018). Humic acids and nitrogen in lettuce seedlings production. Applied Research \& Agrotechnology, 11(1), 69-77. https://doi.org/ 10.5935/PAeT.V11.N1.08

Santos, V. M., Melo, A. V., Cardoso, D. P., Gonçalves, A. H., Sousa, D. C. V., \& Silva A. R. (2017). Using biostimulants growth of soybean Glycine max (L.). Revista Verde, 12(3), 512-517. https://doi.org/10.18378/ rvads.v12i3.4139

Silva, A. C., Canellas, L. P., Olivares, F. L., Dobbss, L. B., Aguiar, N. O., Frade, D. O. R., Rezende, C. E., \& Peres L. E. P. (2011). Root growth of tomato seedlings intensified by humic substances from peat bogs. 
Revista Brasileira de Ciência do Solo, 35(5), 1609-1617. https://doi.org/10.1590/S0100-0683201100 0500015

Silva, L. R., Guimarães, M. G., Freitas, R. J., Pelá, A., \& Carvalho, D. D. C. (2016). Humic acids to obtain higher early fresh matter in 'Pérola' common bean plants. Revista Verde, 11(2), 06-10. https://doi.org/ 10.18378/rvads.v11i2.3936

Silva, R. M., Jablonski, A. S. L., Morselli, T. B. G. A., Garcia, S. S., \& Kroth, P. L. I. (2000a). Production of lettuce grown in nutritive solution with addition of humic substances in vegetative house condition. Revista Cientifica Rural, 05(1), 13-23.

Silva, R. M., Jablonski, A. S. L., Siewerdt, L., \& Silveira Júnior, P. (2000b). Development of Ryegrass Roots as Affected by Humic Compounds Addition to a Complete Nutritive Solution under Greenhouse Conditions. Revista Brasileira de Zootecnia, 29, 1623-1631. https://doi.org/10.1590/S1516-35982000000600005

Sinha, R. K. (2004). Modern Plant Physiology. Boca Raton, FL: CRC Press.

Stitt, M., Müller, C., Matt, P., Gibon, Y., Carillo, P., Morcuende, R., Scheible, W. R., \& Krapp, A. (2002). Steps towards an integrated view of nitrogen metabolism. Journal of Experimental Botany, 53(370), 959-970. https://doi.org/10.1093/jexbot/53.370.959

Tejada, M., \& Gonzalez, J. L. (2003). Influence of foliar fertilization with amino acids and humic acids on productivity and quality of asparagus. Biological Agriculture \& Horticulture, 21(3), $277-291$. https://doi.org/10.1080/01448765.2003.9755270

Valdrighi, M. M., Pera, A., Agnolucci, M., Frassinetti, S., Lunardi. D., \& Vallini, G. (1996). Effects of compost-derived humic acids on vegetable biomass production and microbial growth within a plant (Cichorium intybus)-soil system: A comparative study. Agriculture, Ecosystems \& Environment, 58(2-3), 133-144. https://doi.org/10.1016/0167-8809(96)01031-6

Vavrina, C. S. (2014). Transplant age in vegetable crops. HortTechnology, 8(4), 550-555.

\section{Copyrights}

Copyright for this article is retained by the author(s), with first publication rights granted to the journal.

This is an open-access article distributed under the terms and conditions of the Creative Commons Attribution license (http://creativecommons.org/licenses/by/4.0/). 